\title{
Fusarium wilt biocontrol and tomato growth stimulation, using endophytic bacteria naturally associated with Solanum sodomaeum and S. bonariense plants
}

\author{
Rania Aydi-Ben-Abdallah*, Hayfa Jabnoun-Khiareddine and Mejda Daami-Remadi
}

\begin{abstract}
Background: Fusarium wilt biocontrol using endophytic microorganisms may represent a potentially attractive and environmentally safe alternative since endophytes could better limit disease incidence and severity through inhibition of the systemic fungus progress.

Main body of the abstract: Twenty-three endophytic bacterial isolates, naturally associated with Solanum sodomaeum and Solanum bonariense, were evaluated for their ability to control Fusarium wilt of tomato induced by Fusarium oxysporum f. sp. lycopersici (FOL) and to promote plant growth. Selected endophytic isolates were screened in vivo, using the root dipping and the culture substrate drenching methods. The most bioactive isolates were subjected to morphological and biochemical characterization and subsequent identification through $16 \mathrm{~S}$ rDNA sequencing genes. Seven isolates (Stenotrophomonas maltophilia S23, S24, S26 and S28; Bacillus sp. SV81; Azotobacter chroococcum S11; and Serratia marcescens S14) were found to be the most efficient in reducing disease severity by $82-96 \%$ over control. Treatments with these isolates led to a significant enhancement in growth parameters, estimated at $45.5-61$ and $24.2-70.5 \%$ than the control, in tomato plants infected or not with FOL, respectively. Diffusible and volatile metabolites released from bacterial cultures had significantly limited FOL radial growth. All isolates were positive for indole-3-acetic acid (IAA) production. S. marcescens S14, S. maltophilia S28, and Bacillus sp. SV81 exhibited a positive phosphate solubilization activity. Production of chitinase, protease, pectinase, and hydrogen cyanide were also investigated.
\end{abstract}

Short conclusion: This study clearly demonstrated that endophytic bacteria recovered from these 2 Solanum species can be explored as promising biocontrol agents active against FOL and are able to enhance tomato growth.

Keywords: Biocontrol, Endophytic bacteria, Fusarium oxysporum f. sp. Iycopersici, Tomato growth, Solanum spp

\section{Background}

Tomato (Solanum lycopersicum L.) is an economically important vegetable crop worldwide. However, it is threatened by various soilborne fungal diseases such as Fusarium wilt caused by Fusarium oxysporum f. sp. lycopersici (Sacc.) W.C. Snyder \& H.N. Hans (FOL). This

\footnotetext{
* Correspondence: raniaaydi@yahoo.fr
}

UR13AGR09-Integrated Horticultural Production in the Tunisian Centre-East, Regional Research Centre on Horticulture and Organic Agriculture, University of Sousse, 4042, Chott-Mariem, Sousse, Tunisia fungus is responsible for considerable crop losses (Hussain et al. 2016). Main disease symptoms include chlorosis and progressive leaf wilting, vascular tissue discoloration, stunting, and, in most severe cases, eventual wilt of the entire plant (Aydi Ben Abdallah et al. 2016b).

Disease management is difficult due to the soilborne nature of the causal agent and its ability to colonize the vascular tissues of infected plants and the emergence of new and aggressive pathogen physiological races. Therefore, the use of resistant tomato varieties lost its 
effectiveness as the mutation in Fusarium species. Furthermore, chemical control is now losing its ground due to adverse effects of chemicals on environment and soil microbiota that calls for alternative inputs with low dependency on chemicals for sustainable agriculture (Fatima and Anjum 2017).

The use of endophytic microorganisms as a biological control agent has become an attractive, promising, and eco-friendly alternative since this agent could inhibit the vascular progress of the target pathogen, limiting more efficiently disease incidence and severity (de Lamo et al. 2018; Constantin et al. 2019). These endophytes colonize plant parts without causing any adverse effects. On many hosts, they act as plant growth-promoting, and/or biocontrol agents by direct antagonism or via the host by triggering induced resistance (Constantin et al. 2019; Passari et al. 2019). For instance, endophytic bacteria namely, Bacillus mojavensis was shown able to promote growth of maize plants infected with Fusarium verticillioides (Kalai-Grami et al. 2014). Collimonas arenae Cal35 showed the highest in vitro antifungal activity against FOL, the causal agent of Fusarium wilt of tomato. In field trial, this bacterial isolate was found to be more active when combined with Bacillusbased biofungicide in reducing disease severity and the relative abundance of $F$. oxysporum in the root endosphere of tomato plants challenged with FOL (Doan et al. 2020).

Various mechanisms, such as antibiotics synthesis, cell wall-degrading enzymes, competition for nutrients and minerals, and/or systemic resistance induction, are implicated in pathogen inhibition (Lugtenberg et al. 2013), while plant growth stimulation was achieved through indole-3-acetic acid (IAA) and siderophore production, phosphate solubilization, and nitrogen fixation (Rosenblueth and Martínez-Romero 2006).

More attention was given to wild Solanum species as attractive sources of biologically active molecules with antifungal and antibacterial activities as previously shown for S. torvum (Bari et al. 2010), S. trilobatum and S. surattense (Tuba et al. 2016), and Solanum linnaeanum (Nefzi et al. 2018a). In addition, Solanum spp. were extensively used as potent isolation sources of endophytic bacteria with plant growth-promoting and/or biocontrol properties, as demonstrated for Solanum elaeagnifolium (Aydi Ben Abdallah et al. 2016a), S. trilobatum (Bhuvaneswari et al. 2013), and S. melongena and S. torvum (Achari and Ramesh 2014). Furthermore, fungi naturally associated with S. linnaeanum are used for the biocontrol of Fusarium crown root rot disease and for the enhancement of tomato growth (Nefzi et al. 2018b).

In the present study, bacterial isolates collected from surface-sterilized stems of Solanum sodomaeum and Solanum bonariense were evaluated for their ability to stimulate growth of tomato plants and to control Fusarium wilt.

\section{Material and methods}

\section{Tomato seedling preparation}

Tomato cv. Rio Grande cultivar, susceptible to FOL races 2 and 3, was used in this study. Seedlings were grown in $7 \times 7 \mathrm{~cm}$-alveolus plates, filled with sterilized peat $^{\circ}$ (Floragard Vertriebs $\mathrm{GmbH}$ für gartenbau, Oldenburg), regularly watered and maintained under $16 \mathrm{~h}$ photoperiod, $60-70 \% \mathrm{RH}$, and $20-30{ }^{\circ} \mathrm{C}$ air temperatures. For all trials, seedlings were used at two-true-leaf growth stage.

\section{Pathogen growth conditions}

F. oxysporum f. sp. lycopersici isolate used in this study was originally recovered from tomato plants showing Fusarium wilt symptoms and severe vascular discoloration. The pathogen was re-isolated from artificially infected plants, fulfilling Koch's postulates, and identified in a previous study (Aydi Ben Abdallah et al. 2016b). It was grown on potato dextrose agar (PDA) medium at $25^{\circ} \mathrm{C}$ for 7 days.

\section{Plant sampling and isolation of endophytic bacteria}

Symptomless wild S. sodomaeum and S. bonariense plants, growing nearby tomato-cropping fields with long history of soilborne diseases, were targeted as a source of endophytic bacteria. Stem, leaf, and fruit samples (5 each) were individually disinfected. Twenty pieces $(1 \mathrm{~cm}$ in length) of sterilized organ tissues were aseptically placed onto nutrient agar (NA) medium (Aydi Ben Abdallah et al. 2016b). Three stem pieces were also pressed using a sterile-nipper and the released liquid was spread on NA medium. The disinfection process efficiency was checked as previously detailed (Aydi Ben Abdallah et al. 2016a). Plates were maintained for $48 \mathrm{~h}$ at $25^{\circ} \mathrm{C}$. Developing bacterial colonies showing distinct macro-morphological traits were picked separately onto NA. Before their use in different assays, stock cultures maintained at $-20{ }^{\circ} \mathrm{C}$ in nutrient broth (NB) added $40 \%$ glycerol were cultured at $25^{\circ} \mathrm{C}$ for $48 \mathrm{~h}$ onto NA.

\section{Endophytic colonization ability}

Collected bacterial isolates were cultured to NA supplemented with $100 \mu \mathrm{g} / \mathrm{ml} \mathrm{(w/v)} \mathrm{of} \mathrm{streptomycin} \mathrm{sulfate}$ and $100 \mu \mathrm{g} / \mathrm{ml}(\mathrm{w} / \mathrm{v})$ of rifampicin (Chen et al. 1995). Those behaving as resistant to both antibiotics were further investigated for their endophytic potential when applied onto tomato seedlings. The wild-type ones were used for tomato $\mathrm{cv}$. Rio Grande inoculation using the root dipping method. Control seedlings were soaked in sterile distilled water (SDW) only. Seedlings were transferred to individual pots $(12.5 \mathrm{~cm} \times 14.5 \mathrm{~cm})$ filled with commercialized peat. Five seedlings were used for each individual treatment. At 60 days post-inoculation, inoculated isolates were re-isolated on NA amended with both 
antibiotics. After incubation at $25^{\circ} \mathrm{C}$ for $48 \mathrm{~h}$, bacterial colonies showing similar morphological traits as the wildtype ones were selected and classified as endophytes.

\section{Hypersensitivity reaction and hemolytic activity}

Hypersensitivity test was carried out according to Nawangsih et al. (2011) method. Isolates leading to the formation of chlorotic and/or necrotic zones on inoculated leaf areas were considered phytopathogens and removed from the next trials. Endophytic isolates were tested for their capacity to degrade hemoglobin according to Murray et al. (2003) protocol. Isolates showing a positive hemolytic activity, as determined by the development of clear zones around their colonies, were classified as human pathogens and excluded from further investigations.

\section{Assessment of plant growth-promoting ability}

Selected endophytic isolates were evaluated for their plant growth-promoting ability. Treated and control seedlings (two-true-leaf stage) were root dipped for 30 min into bacterial cell suspensions $\left(\sim 10^{8}\right.$ cells $\left./ \mathrm{ml}\right)$ and SDW, respectively. They were potted in sterile peat, maintained under the same greenhouse conditions as described above for about 30 and 60 days, and regularly watered with tap water. Five seedlings were used for each individual treatment. At the end of the trial, tomato plants were uprooted and washed for removing adhering peat. Various growth parameters were noted for all tomato plants (namely, height, aerial parts and roots fresh weights, and maximum root length and fresh weight).

\section{Assessment of disease suppression ability}

Tested endophytic isolates were challenged to tomato cv. Rio Grande seedlings (two-true-leaf stage) using the culture substrate drenching method with $25 \mathrm{ml}$ of a bacterial cell suspensions containing $10^{8}$ cells $/ \mathrm{ml}$. Pathogen inoculation was applied, 6 days after bacterial challenge, through substrate drench with equal volume of a conidial suspension $\left(10^{6}\right.$ conidia/ml $)$. Un-inoculated control seedlings were watered by an equal volume of SDW (negative control). Positive control plants were FOLinoculated but treated with SDW only. Each individual treatment was replicated five times (five seedlings per treatment). Fusarium wilt severity was evaluated, 30 and 60 days post-inoculation (DPI), on FOL-infected tomato plants based on intensity of leaf yellowing and necrosis using a 0-4 scale (Amini 2009). The vascular browning extent (from collar), plant height, fresh weight of the whole plant, roots' fresh weight, and FOL re-isolation frequency were also noted. FOL re-isolation frequency was calculated. The most active bacterial isolates, showing significant ability to efficiently control tomato Fusarium wilt, were selected for a series of characterizations.

\section{Characterization and identification of efficient endophytes}

Colonies of selected isolates were morphologically characterized based on their form, margin, elevation, surface, opacity, and color on NA medium (Patel et al. 212). Gram staining was determined using light microscopy. They were also characterized using conventional biochemical tests according to Schaad et al. (2001) protocols. Molecular identification was undertaken after extraction of the genomic DNA. The PCR conditions and the 2 universal eubacterial primers $27 \mathrm{f}$ and1492r used for amplification of $16 \mathrm{~S}$ rDNA gene were detailed in a previous work (Aydi Ben Abdallah et al. 2016a). The homology of the 16S rDNA sequence of a given isolate was performed, using BLAST-N program from GenBank database (www.ncbi.nlm.gov/BLAST/). Alignment of sequences was performed using the ClustalX (1.81).

\section{Antifungal activity of selected endophytic isolates}

The antifungal activity of selected endophytic isolates against FOL was assessed using the streak and the disk diffusion methods on PDA medium (Aydi Ben Abdallah et al. 2015). SDW was used as control. Each individual treatment was replicated 4 times. After 4 days of incubation at $25^{\circ} \mathrm{C}$, effects of tested treatments were evaluated based on FOL colony diameter and the diameter of the inhibition zone. For the assessment of the antifungal activity of volatile metabolites, a sealed plate method was used (Aydi Ben Abdallah et al. 2015). The plates were incubated at $25^{\circ} \mathrm{C}$ for 7 days. Three plates were used for each individual treatment. The effect of tested treatments was assessed based on pathogen mycelial growth inhibition (Tiru et al. 2013).

\section{Hydrolytic enzyme production}

Chitinase, pectinase, and protease production of selected isolates was tested according to Tiru et al. (2013). Treatments were performed in triplicate. After $48 \mathrm{~h}$ to $72 \mathrm{~h}$ of incubation at $28 \pm 2{ }^{\circ} \mathrm{C}$, isolates showing the presence of clear zones around their colonies were classified as chitinase-, pectinase-, and protease-producing agents.

\section{Hydrogen cyanide ( $\mathrm{HCN}$ ) production}

Hydrogen cyanide $(\mathrm{HCN})$ production was determined qualitatively (Sgroy et al. 2009). Treatments were performed in triplicate. Plates were sealed with parafilm and incubated at $25^{\circ} \mathrm{C}$ for 4 days. Change in color from yellow to light-reddish brown indicates positive $\mathrm{HCN}$ production.

\section{Phosphate solubilization capacity}

Phosphate solubilization ability was determined according to Sgroy et al. (2009) protocol. The test was performed in triplicate. After 7 days of incubation at $28 \pm$ $2{ }^{\circ} \mathrm{C}$, the clearing zone formed around colonies was noted. 


\section{Indole-3-acetic acid (IAA) production}

IAA production was determined according to Sgroy et al. (2009) protocol. Treatments were performed in triplicate. Absorbance was read at $530 \mathrm{~nm}$. IAA concentration was determined based on a standard curve performed from IAA dilution series at $100 \mu \mathrm{g} / \mathrm{ml}(\mathrm{w} / \mathrm{v})$ in LB medium.

\section{Statistical analysis}

A one-way analysis of variance (ANOVA) was used for data analysis. The software used is the Statistical Package for the Social Sciences (SPSS) for Windows version 16.0. Experiments were undertaken according to a completely randomized design. Means were compared using Student-Newman-Keuls test at $P \leq 0.05$. Correlations between disease severity and plant growth parameters were carried out using bivariate Pearson's test at $P \leq 0.05$.

\section{Results and discussion}

Endophytic behavior of bacterial isolates was collected from S. sodomaeum and S. bonariense.

Twenty-five bacterial isolates, recovered from stems, leaves, and fruits of S. sodomaeum and S. bonariense, showed double-resistance to streptomycin sulfate and rifampicin $(100 \mu \mathrm{g} / \mathrm{ml} \mathrm{w} / \mathrm{v})$. When inoculated to tomato cv. Rio Grande plants, only 23 isolates were re-isolated from tomato stem tissues when plated on NA medium amended with both antibiotics. These 23isolates were selected for their growthpromoting and disease suppression abilities. All plants were inhabited by diverse bacteria known as endophytes.

Wild solanaceous plants species, i.e., Datura spp. (Aydi Ben Abdallah et al. 2016b and c), Nicotiana glauca (Aydi Ben Abdallah et al. 2016d), Withania somnifera (Aydi Ben Abdallah et al. 2016e), S. elaeagnifolium (Aydi Ben Abdallah et al. 2016a), and S. linnaeanum (Nefzi et al. 2018b) have been widely investigated as isolation source for beneficial endophytic bacteria and/or fungi. In the present study, S. sodomaeum and S. bonariense were explored for their naturally associated endophytic bacteria, with tomato growth promotion and Fusarium wilt control abilities.

Currently, microbial endophytic communities are the focus of several studies aiming unraveling and clarifying of their roles as plant growth promoters and their significant involvement in plant health (Vurukonda et al. 2018). Bacteria that colonize the internal tissues of plants seem to have an ecological advantage over bacteria than can only colonize plants epiphytically. The internal tissues of plants possibly provide a more uniform and protective environment for microorganisms than plant surface (Wang et al. 2013).

\section{Growth-promoting potential noted on pathogen-free tomato plants}

All tomato cv. Rio Grande plants separately inoculated with the 23 endophytic isolates remained symptomless until the end of the trial (30 and 60 days postinoculation). Their growth-promoting ability was assessed based on various parameters.

At 30 and 60 days post-inoculation, all noted growth parameters (height, maximum root length, aerial part fresh weight, and root fresh weight), varied significantly (at $P \leq$ $0.05)$ depending on tested bacterial treatments. As presented in Fig. 1, treating tomato plants with 18 strains out of the 23 tested resulted in significant increment of plant height, by $22.2-36.9 \%$, than the controls. The highest increase (36.9\%) was achieved, using SV81, and followed by 35.3\% using S11 treatment. The aerial part fresh weight recorded on plants treated with all tested bacterial isolates was also significantly enhanced by $34.1-70.5 \%$ versus control. The highest weight increase (69.5-70.5\%) was noted, following S14 and S11 treatments and at a lesser extent S24 (63.3\%). The root development, as estimated based on the maximum root length, was also significantly increased by 22.2 to $38.7 \%$ versus control, following the treatments with 10 tested isolates (namely S11, S14, S23, S24, S26, S28, S29, SV71, SV77, and SV81; Fig. 1). The root fresh weight was also significantly augmented by 30.9 to $52.2 \%$ over control, following the treatments with S11, S14, S23, S24, S26, S28, SV77, and SV81 isolates. The greatest increase of this parameter, of about $51.5-52.2 \%$ over control, was achieved at S14 and S11 isolates, followed by $39.6-40.9 \%$ noted, using S24 and S23.

These endophytic microorganisms provide real advantages to the host plants, for example, by enhancing the physiological activity of the plant or facilitating the uptake of nutrients from the soil. Thus, they may serve as plant growth promoters (Vurukonda et al. 2018). Some bacterial endophytes provide an advantage to the host they colonize over non-infected plants. These organisms are capable of promoting plant growth both directly and indirectly. Endophytes can promote growth directly by the production and/or the regulation of plant growth hormones, the nitrogen fixation, and the phosphate solubilization. Indirectly, bacterial endophytes promote plant growth by protecting the plant against pathogens (Aydi Ben Abdallah et al. 2019 and Ben Slama et al. 2019). The inoculation of mung beans (Vigna radiata) with Streptomyces thermocarboxydus S3 showed a significant increase in fresh weight, root length, and total length in the presence of IAA production as also state by Lasudee et al. (2018).

\section{Growth-promoting potential noted on pathogen- inoculated tomato plants}

When tested onto FOL-inoculated tomato plants, bacterial treatments had significantly (at $P \leq 0.05$ ) affected all growth parameters noted 30 and 60 days posttreatment. As shown in Fig. 2, treatments with S10, S11, S14, S23, S24, S26, S27, S28, S29, and SV81 isolates had significantly improved plant height and fresh weight by 

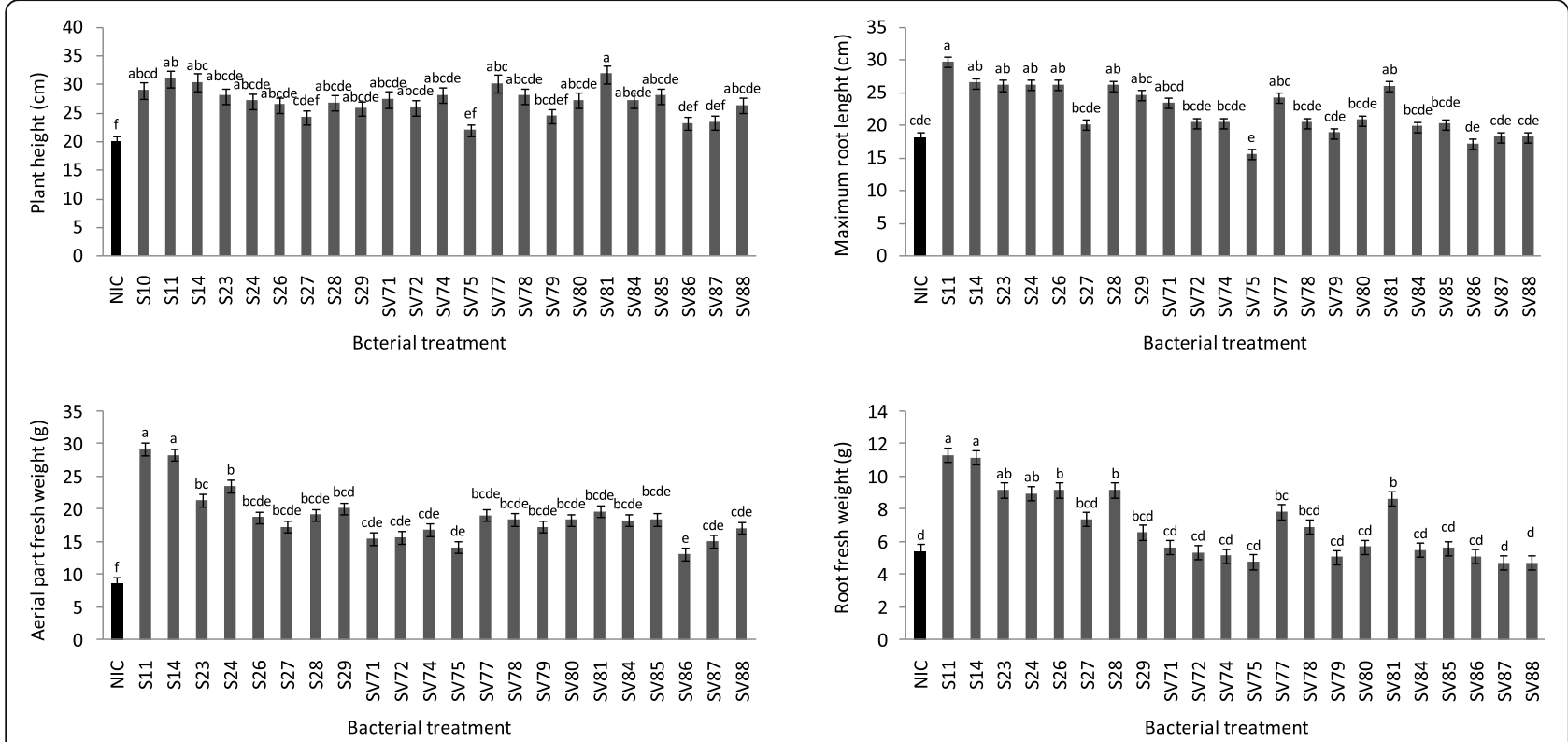

Fig. 1 Plant growth-promoting potential of various endophytic bacterial isolates, recovered from Solanum sodomaeum and S. bonariense, noted on pathogen-free tomato cV. Rio Grande plants 60 days post-treatment. S11, S14, S26, S27, S28, and S29 are isolates issued from S. sodomaeum. S23, S24, SV71, SV72, SV74, SV75, SV77, SV78, SV79, SV80, SV81, SV84, SV85, SV86, SV87 and SV88 are bacterial isolates recovered from S. bonariense. $\mathrm{NIC}$, untreated control. Bars sharing the same letter are not significantly different according to Student-Newman-Keuls test at $P \leq 0.05$

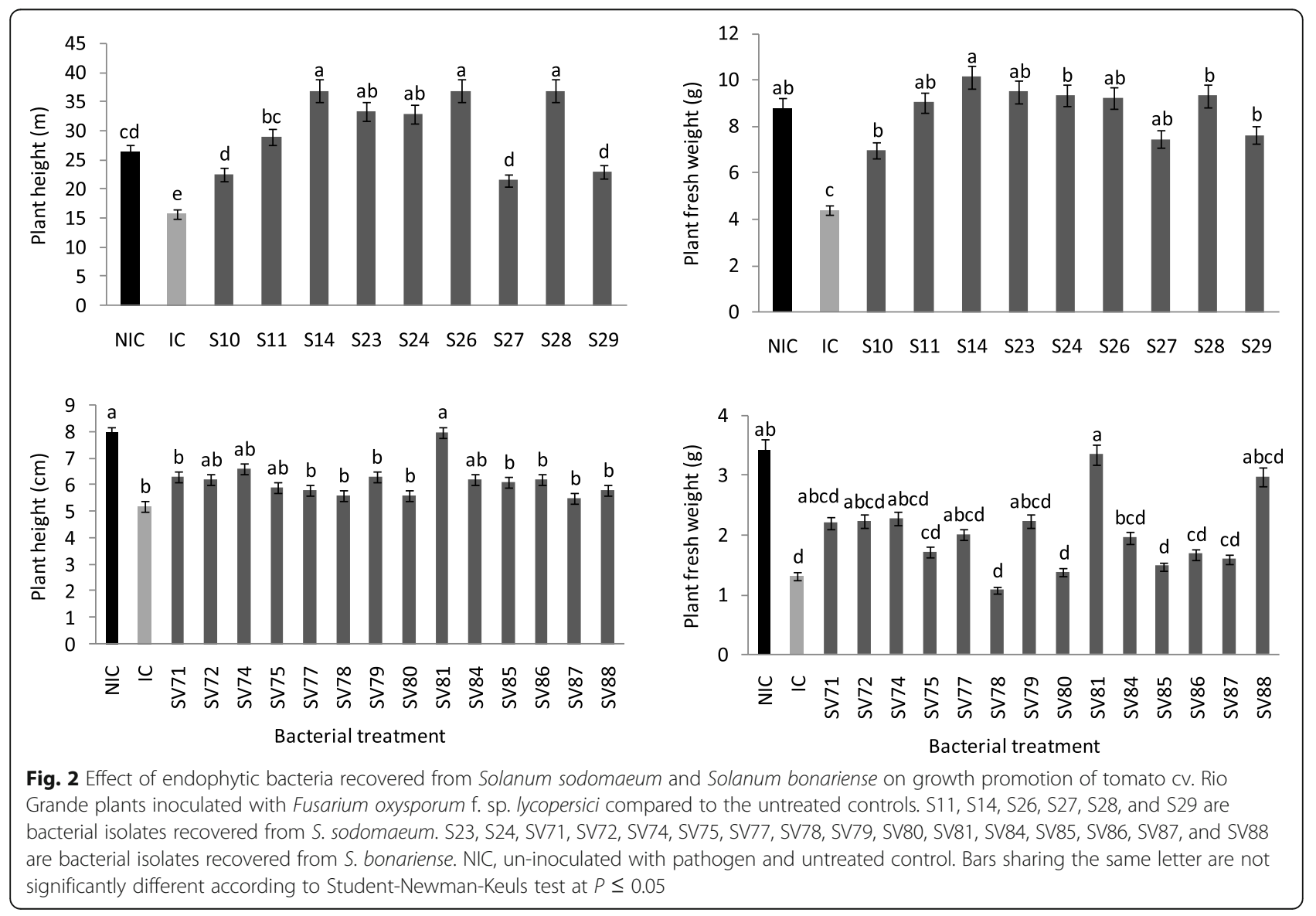


26.8-57.3 and 36.7-61\%, respectively, over pathogeninoculated and untreated control. It should be also noted that tomato plants infected with FOL and treated with these isolates showed significantly similar growth as disease-free and untreated controls. Furthermore, tomato plants inoculated with FOL and subjected to S14-, S26-, S28-, S23-, and S24-based treatments were significantly longer than the un-inoculated and the untreated control plants.

Obtained results clearly indicated that the majority of tested bacterial isolates enhanced the aerial part growth and root development on pathogen-free and FOLinoculated tomato plants. Similar results were previously reported on plant growth-promoting ability displayed by endophytic Pseudomonas spp. (P. aeruginosa HR7 and Pseudomonas sp.) recovered from symptomless tomato roots and stems (Patel et al. 2012). An endophytic $B$. amyloliquefaciens JK-SD002, recovered from tomato stems, augmented also height of treated tomato plants (Nawangsih et al. 2011). In Selvakumar et al. (2008) study, growth improvement was also observed on wheat seedlings treated with endophytic $S$. marcescens KR-4, Bacillus thuringiensis KR-1, and Enterobacter asburiae KR-3, isolated from Puerariathun bergiana nodules. In the recent findings, diverse endophytic Bacillus cereus S42, Alcaligenes faecalis S18, B. mojavensis S40, Stenotrophomonas maltophilia S37, Pseudomonas sp. S85, Bacillus sp. SV101, and Bacillus tequilensis SV104 isolates, obtained from various wild Solanaceae species, also exhibited growth-promoting ability, when used for the treatment of tomato plants inoculated or not with FOL (Aydi Ben Abdallah et al. 2016a, 2016b, 2016d). Seed coating with endophytic bacteria promoted tomato plant growth and quality of tomato production in plants challenged or not with FOL (Koohakan et al. 2020).

Consequently, intimate and non-harmful associations can be established between bacteria and their host plants. This is the biggest difference between endophytes and plant growth-promoting rhizobacteria (PGPR) (Timmusk et al. 2017). There are several mechanisms by which endophytic bacteria offer several benefits to their host plants, particularly via the growth promotion, and their protection against biotic and abiotic stresses (Kha et al. 2018). The beneficial effect of plant growthpromoting bacteria (PGPB), including endophytic bacteria, on plant physiology may be also attributed to their ability to tolerate biotic stresses such as infections by pathogenic bacteria and fungi, insect attacks, and native plants colonization (Egamberdieva et al. 2017). Several questions regarding the association of endophytic microorganisms with host plants, however, are still unanswered, including how long do they reside in the host and do they have any impact on photosynthesis. It appears evident that microbes can augment biotic stress tolerance in plants through the PGPB process (Passari et al. 2019). Indeed, PGPB are known to produce various enzymes including amylase, chitinase, cellulase, invertase, lipase, keratinase, peroxidase, pectinase, protease, phytase, and xylanase which transform the complex nutrients into simple mineral forms. This nutrient cycling capacity makes them ideal candidates for natural fertilizers (Vurukonda et al. 2018).

\section{Disease suppression potential of selected endophytic isolates}

At 30 and 60 DPI with FOL, disease severity, noted on tomato plants varied significantly (at $P \leq 0.05$ ) upon bacterial treatments tested. Significant decreases in the leaf damage and in the vascular browning extent by 35.3-94.1 and $19.5-96.3 \%$ over control, respectively, were noted on tomato plants infected with FOL and treated with S10, S11, S14, S23, S24, S26, S27, S28, S29, and SV81 (Fig. 3). The highest decreases in disease severity and in the vascular browning extent of about 83.3-94.1 and 82-96.3\%, respectively, were achieved, using S11, S14, S23, S24, S26, S28, and SV81 treatments. It should be noted that tomato plants inoculated with FOL and treated with these seven isolates were significantly similar to disease-free and untreated controls. FOL re-isolation frequency from tomato stems of FOL-inoculated plants treated with S11, S14, S23, S24, S26, S28, and SV81 isolates was lowered by $90 \%$ than the control (Fig. 3). These 7 isolates were selected for further characterizations.

Later discovery of the metabolic potential of such endophytes in planta, their ability to efficiently compete with other endophytes including plant pathogens, and their role in stimulating the expression or over-expression of plant genomic sequences involved in tolerance to plant stresses indicated that selected endophytes may be considered a very promising agent to control plant pests and diseases (Vurukonda et al. 2018). Multiple reports demonstrated the capacities of Bacillus strains to control Fusarium-induced plant diseases. The antagonistic capacities of endophytic bacteria are associated to their plant growthpromoting abilities, either directly and indirectly under normal and stress conditions (Ben Slama et al. 2019). Biocontrol ensured by endophytic bacteria along the different steps of the infection process may be achieved through antibiosis, competition with the target pathogens for nutrients and space and through the induction of disease resistance in the host plant that they colonize. Therefore, protection of plants from biotic stresses may be the result of one or more microbe-microbe or plant-microbe interactions (Vurukonda et al. 2018).

In this study, during pathogenic infection, endophytic association mitigated the disease and improved the growth and biomass of tomato; this may be due to inhibition of pathogenic infection, stimulation of plant 


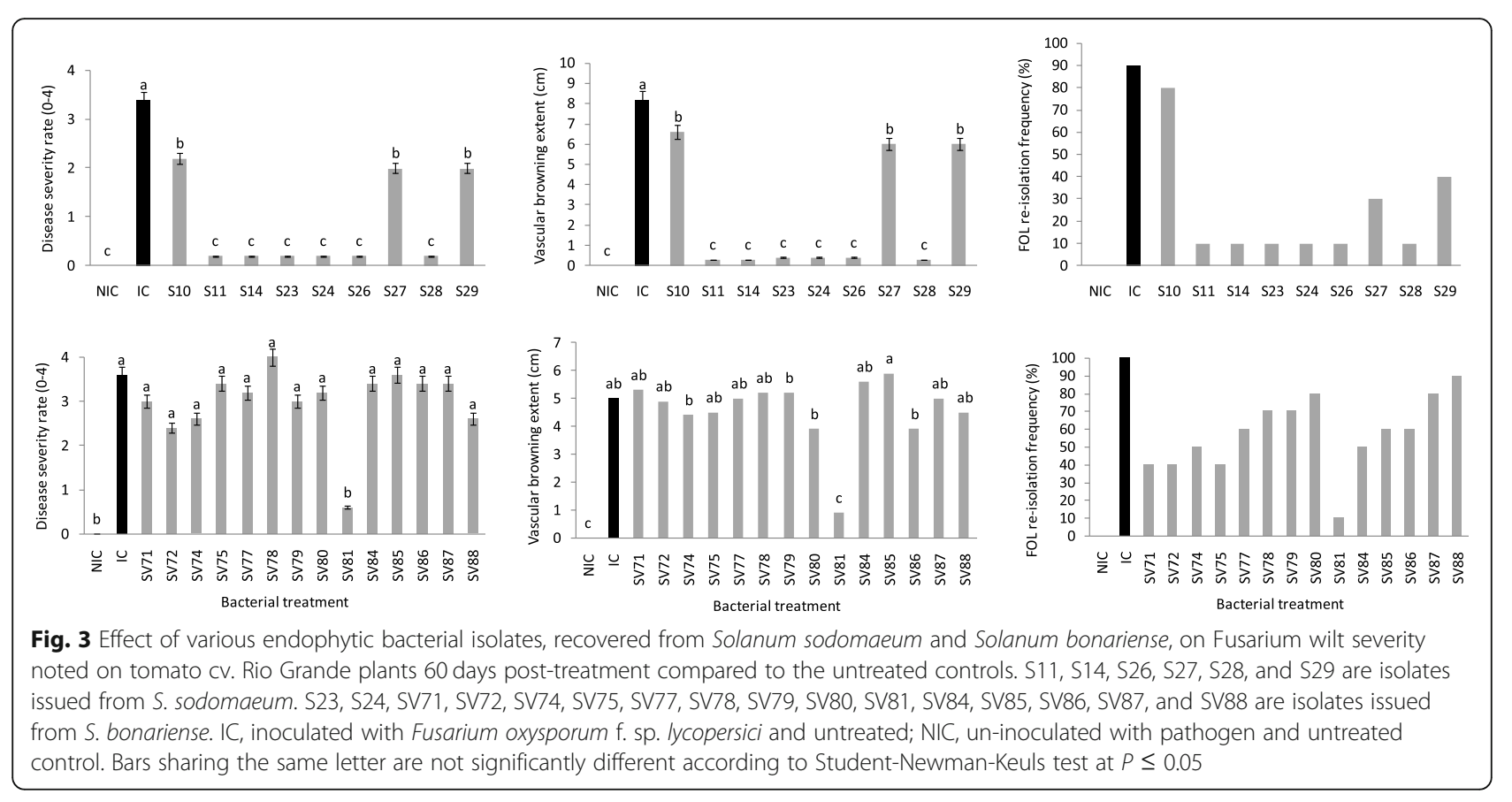

resistance, high nutrient uptake, and promotion of plant growth. Waqas et al. (2015) showed that endophytes able to produce siderophores and organic acids are helpful in combating pathogenic effects in sunflower plants. Furthermore, the defense hormones regulation might be correlated with the ability of endophytic bacterial strain RWL-1 to produce organic acids (succinic acid, acetic acid, propionic acid, and citric acid) during the inoculation and infection of tomato plants with FOL (Shahzad et al. 2017). Tomato plants challenged or not with FOL and treated with endophytic B. amyloliquefaciens subsp. plantarum SV65 showed significant expression of PRs and lipooxygenase genes than in the untreated ones. This bacterial strain was also able to produce chitinase, protease, organic acids, siderophores, and fengycines. These metabolites may be involved in bio-protection against FOL by direct inhibition of the pathogen and/or by inducing tomato systemic resistance (Aydi Ben Abdallah et al. 2017). Further studies are needed to ascertain secondary metabolites produced by bacterial entophytes and determine their role in plant defense against pathogenic infection-induced stresses. Furthermore, the use of a biocontrol agent as one of the natural enemy of soilborne pathogens besides the enhancement of the crop production potential can provide a complementary tactic for sustainable integrated pest management (Fatima and Anjum 2017).

\section{Correlation between disease severity and plant growth parameters}

Pearson's correlation analysis indicated that the lowered disease severity, estimated based on the leaf damage index and the vascular browning extent, was associated by significant increases in all plant growth parameters. In fact, height was negatively correlated to the leaf damage index $(r=-0.893, P=2.111 \mathrm{E}-4)$ and to the vascular browning extent $(r=-0.888, P=2.620 \mathrm{E}-4)$. The plant fresh weight was negatively linked to the leaf yellowing score $(r=-0.934, P=2.537 \mathrm{E}-5)$ and to the vascular browning extent $(r=-0.918, P=6.877 \mathrm{E}-5)$. Similar trend was observed between FOL re-isolation frequency and plant growth parameters where negative correlations were recorded between pathogen reisolation frequency, plant height $(r=-0.781, P=0.005)$, and whole plant fresh weight $(r=-0.913, P=8.614 \mathrm{E}-$ $5)$.

In addition to growth promotion, an important Fusarium wilt-suppressive ability was reached, in the current study, using the seven selected bacterial isolates (namely S11, S14, S23, S24, S26, S28 and SV81) comparatively to the control. Fusarium wilt biocontrol was associated with a reduced colonization of the vascular tissues thus leading to indirect growth improvement. Similar results were cited by Ramyabharathi and Raguchander (2014) showing that Bacillus subtilis EPC016-treated and FOLinfected tomato plants exhibited reduced disease severity and improved plant growth. Aydi Ben Abdallah et al. (2016a, b, d and e) found that the following treatments with endophytic Bacillus, Stenotrophomonas, Pseudomonas, and Alcaligenes isolated from N. glauca, Datura metel, S. elaeagnifolium, and W. somnifera, Fusarium wilt-suppressive effect was associated to tomato growth improvement. Similarly, growth promotions were also recorded on maize plants bacterized with an endophytic 
B. mojavensis and infected with $F$. verticillioides (KalaiGrami et al. 2014). Tests on infested soil with F. oxysporum, tomato plants treated with endophytic bacteria B. subtilis SV41, and B. amyloliquefaciens subsp. plantarum SV65 showed diversity on soil microbial community structures, enhancement on plant height, and fruit production accompanied with a decrease on Fusarium wilt severity compared to untreated ones (AydiBenAbdallah et al. 2019). Enhanced growth may also be exerted by improved nutrient acquisition. This increased capacity for nutrient uptake could contribute to diminishing the deleterious effect of the pathogen (Deketelaer et al. 2017). Plant growth promotion and productivity stimulated by microbial endophytic communities are often associated with increased plant health, achieved through direct and/or plant-mediated control of plant pathogens (Vurukonda et al. 2018).

\section{Characterization and identification of the seven selected isolates}

The 7 bioactive isolates selected above (namely S11, S14, S23, S24, S26, S28, and SV81) on the base of their effectiveness in Fusarium wilt suppression and tomato growth promotion even in FOL-inoculated plants were morphologically and biochemically characterized (Table 1). These isolates were also checked for their hypersensitivity reaction and their hemolytic activity and were found negative for these both tests.

Blast- $\mathrm{N}$ analysis of sequenced $16 \mathrm{~S}$ rDNA gene homology indicated that S28, S23, S24, and S26 isolates were affiliated to the genus of Stenotrophomonas with $99.9 \%$ similarity to $S$. maltophilia RPS $4,99.5 \%$ to $S$.

Table 1 Biochemical characterization and Gram staining of selected endophytic bacterial isolates recovered from Solanum sodomaeum and S. bonariense plants

\begin{tabular}{llllllllll}
\hline Solanum spp. & \multicolumn{3}{l}{ S. sodomaeum } & & \multicolumn{3}{l}{ S. bonariense } \\
\cline { 2 - 5 } \cline { 6 - 8 } Bacterial isolates & S11 & S14 & S28 & S26 & & S23 & S24 & SV81 \\
\hline Catalse & + & + & + & + & + & + & + \\
Lecithinase & + & - & - & - & + & - & - \\
Urease & + & - & + & - & + & - & + \\
Nitrate reductase & + & + & + & + & + & + & + \\
Tryptophane deaminase & - & - & - & + & - & - & - \\
Lysine decarboxylase & - & - & - & - & - & - & - \\
Indole & + & + & + & + & + & + & + \\
Mannitol & + & + & + & + & - & + & + \\
Simmons Citrate & + & - & + & - & - & - & - \\
Red of methyl & + & - & - & - & + & - & - \\
Vosges-Proskauer & - & + & + & + & - & + & + \\
King A & - & - & - & - & - & - & - \\
Gram staining & - & - & - & - & - & - & + \\
\hline
\end{tabular}

"+", positive test; "-", negative test maltophilia PPA N3, and 99.1-99.8\% to S. maltophilia Ysm, respectively. The isolate SV81 was identified as $\mathrm{Ba}$ cillus sp. with $99.7 \%$ of similarity to Bacillus sp. hb122. The isolate S14 shared identical similarity to Serratia marcescens $35 \mathrm{dr}$ and the isolate S11 belonged to Azotobacter with $98.4 \%$ of similarity to Azotobacter chroococcum ABA-1 (Fig. 4). Sequences of S11, S14, S23, S24, S26, S28, and SV81 were submitted to GenBank and attributed the following accession numbers KR818078 to KR818083 and KU994900, respectively.

Zhu et al. (2012) pointed out that the significant role of play by the endophyte $S$. maltophilia in agricultural production, as a plant growth-promoting agent. Algam et al. (2005) reported that endophytic Brevibacillus brevis $\mathrm{B} 2$ and B. subtilis strains $\mathrm{B} 5, \mathrm{~B} 7$, and $\mathrm{B} 8$, isolated from tomato rhizosphere, also were able to promote growth and to suppress bacterial wilt induced by Ralstonia solanacearum. Mrkova-Ki et al. (2001) demonstrated also that $A$. chroococcum displayed growth and yieldpromoting abilities of field-grown beets. Gyaneshwar et al. (2001) showed also the similar potential of endophytic S. marcescens recovered from rice plants. In the same sense, cyclamen plants, bacterized with $S$. marcescens B2 and inoculated with Rhizoctonia solani sclerotia and/or Fusarium oxysporum f. sp. cyclaminis conidia, did not develop any disease symptoms and were found to be healthy (Someya et al. 2000).

\section{Antifungal activity of the selected bacterial isolates}

Tested using the streak method, the 7 isolates had significantly $(P \leq 0.05)$ reduced FOL radial growth compared to control (Fig. 5a). The highest decrease in FOL mycelial growth, by 38.4 and $45.4 \%$, was noted on pathogen cultures co-cultured with S. maltophilia S23 and Bacillus sp. SV81, respectively. Also, S. maltophilia S23, S. maltophilia S24, and Bacillus sp. SV81 formed inhibition zones of $11.5-12.75 \mathrm{~mm}$ in diameter, which were significantly $(P \leq 0.05)$ higher than those induced by the remaining tested isolates $(7.75-8.5 \mathrm{~mm}$ in diameter; Fig. 5b). Using the sealed plate method, only Bacillus sp. SV81 exhibited a significant inhibitory effect $(P \leq 0.05)$ against the target pathogen as expressed by $31.8 \%$ lower FOL growth versus control. This revealed the ability of Bacillus sp. SV81 to inhibit pathogen at distance through its antifungal volatile compounds (Fig. 5a).

Assessed in vitro for their antifungal activity against FOL growth, the 7 selected isolates had inhibited pathogen radial growth through the release of diffusible and volatile metabolites. Similar results were noted by Aydi Ben Abdallah et al. (2015) using others bacterial isolates. In fact, they showed that endophytic Bacillus spp., isolated from wild Solanaceae stems, released diffusible and volatile compounds which are bioactive against FOL growth. Chaurasia et al. (2005) demonstrated the 


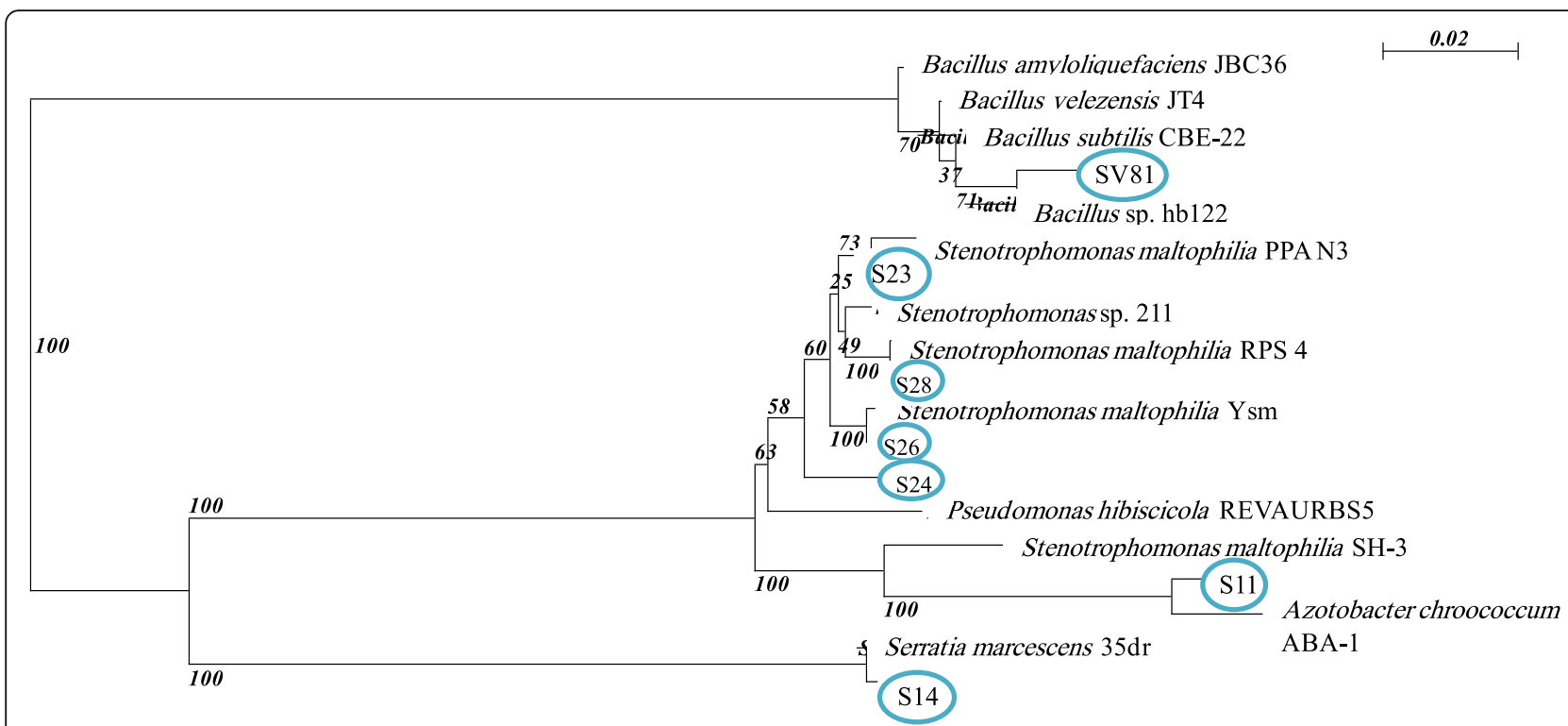

Fig. 4 Neighbor-joining phylogenetic tree of 16 S rDNA sequences of SV81, S23, S28, S26, S24, S11, and S14 isolates and their closest phylogenetic relatives. The nucleotide sequences used of representative isolates were obtained from Genbank database under the following accession numbers: KF494187 (Azotobacter chroococcum ABA-1), GQ884174 (Stenotrophomonas maltophilia SH-3), MT555732 (Pseudomonas hibiscicola REVAURBS5), KJ729606 (Serratia marcescens 35dr), JQ308605 (Stenotrophomonas maltophilia RPS 4), KF278963 (Stenotrophomonas maltophilia Ysm), JQ308603 (Stenotrophomonas maltophilia PPA N3), KT034429 (Stenotrophomonas sp. 211), KF863899 (Bacillus sp. hb122), JX418320 (Bacillus amyloliquefaciens JBC36), MK928419 (Bacillus velezensis JT4), MT026940 (Bacillus subtilis CBE-22), and for the bacterial isolates tested KR818078 (S11), KR818079 (S14), KR818080 (S23), KR818081 (S24), KR818082 (S26), KR818083 (S28), and KU994900 (Bacillus sp. SV81). The tree topology was constructed using ClustalX (1.81)

inhibitory effect of diffusible and volatile metabolites from $B$. subtilis against some plant fungi including $F$. oxysporum. The basis for the observed activity of selected bacterial isolates against FOL has been linked to secondary metabolites that strongly interfere with fungal pathogens.

\section{Antifungal activity features of the selected bacterial isolates \\ Enzymatic activity}

All tested bacterial isolates displayed pectinolytic activity when grown on pectin-agar medium. As for chitinase activity, 6 isolates, except S. maltophilia S26, showed clear zones around colonies when cultured on chitin-agar medium and were found to be chitinase-producing agents. For protease production, except Bacillus sp. SV81, the remaining 6 isolates displayed positive activity (Table 2). The greatest activity was noted at A. chroococcum S11, S. maltophilia S23, and S. maltophilia S24 cultures, where the clear zone formed around their colonies reached $30-45.83 \mathrm{~mm}$ in diameter. In the present study, the selected bacterial agents were evaluated in vitro for their traits implicated in their antifungal potential. All selected isolates were found to be pectinase-producing agent. In the present study, 6 bacterial isolates are chitinase- and protease-producing agent, except $S$. maltophilia S26 and Bacillus sp. SV81. Therefore, their antifungal potential against Fusarium wilt agent may be attributed in part to their capacity to produce chitinases and/or proteases. Antagonistic bacteria such as Bacillus, Burkholderia, Serratia, Acinetobacter, Pseudomonas, Enterobacter, and Stenotrophomonas were widely known by their chitinase, protease, and $\beta-1,3-$ glucanase activities (Berg et al. 2005). Microorganisms with extracellular enzyme activities are not only helpful in organic matter decomposition and plant growth-promoting, but also play an important role in disease suppression by antagonizing soilborne pathogens and facilitating intracellular colonization and development of endophytism (Ben Slama et al. 2019).

\section{HCN production}

Only A. chroococcum S11 and S. maltophilia S28 were shown to be able to modify the filter paper color from yellow to light-reddish color which indicated their $\mathrm{HCN}$ production potential when grown on NA medium amended with glycine (Table 2).

The production of $\mathrm{HCN}$ plays an important role in disease suppression of crop plants (Ben Slama et al. 2019). The registered antifungal activity displayed by S. maltophilia S28 and A. chroococcum S11 may due, in part, to the production of $\mathrm{HCN}$. This volatile antibiotic, frequently produced by Gram-negative bacteria, such as $P$. fluorescens, S. maltophilia S37, and A. 

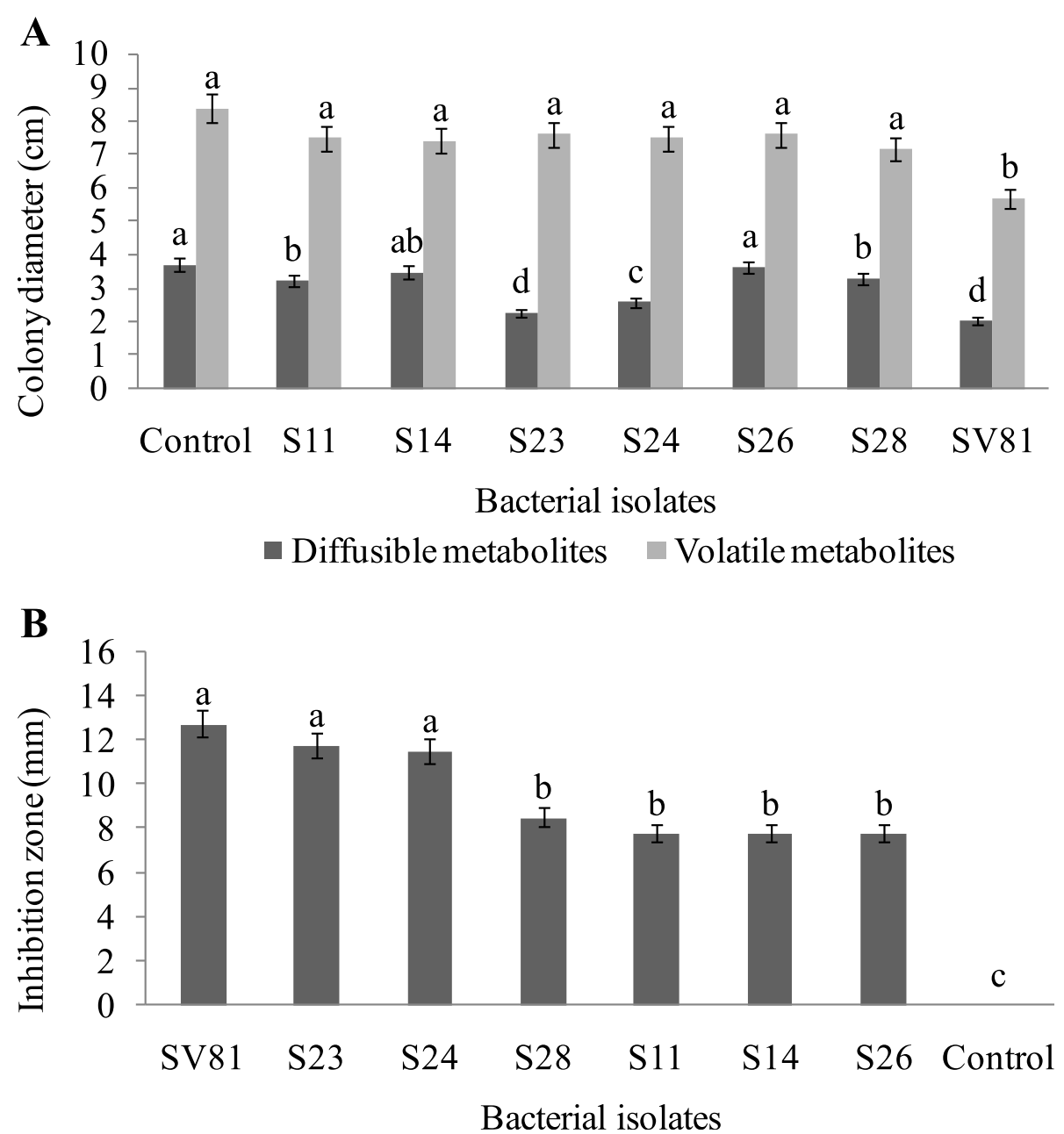

Fig. 5 Antifungal activity of the seven selected bacterial isolates, recovered from Solanum sodomaeum and Solanum bonariense, toward Fusarium oxysporum f. sp. Iycopersici noted after 4 and 7 days of incubation at $25^{\circ} \mathrm{C}$. S11, Azotobacter chroococcum; S14, Serratia marcescens; S23, S24, S26 and S28, Stenotrophomonas maltophilia; SV81: Bacillus sp. For each test, values with the same letter are not significantly different according to Student-Newman-Keuls test at $P \leq 0.05$

faecalis S8, proved to be deployed in $R$. solani (Nagarajkumar et al. 2004) and/or FOL (Aydi Ben Abdallah et al. 2016c and d) biocontrol.

\section{Plant growth-promoting traits of the selected isolates Phosphate solubilization}

Serratia marcescens S14, Bacillus sp. SV81, and S. maltophilia S28 were able to solubilize phosphate as determined by the formation of a clear zone of about 8.33 and $13.17 \mathrm{~mm}$ in diameter around their colonies, respectively (Table 2).

As phosphorus mostly occurs in the soil in an insoluble form, the intervention of phosphatesolubilizing endophytic bacteria becomes important for plants (Ben Slama et al. 2019). In this study, 3 isolates (S. marcescens S14, Bacillus sp. SV81, and S. maltophilia S28) out of the7 tested were phosphate producers. Therefore, the plant growth-promoting potential induced by these 3 isolates in tomato plants inoculated or not with the pathogen may be due to their ability to solubilize the phosphate and facilitate its uptake by plant. Bacillus species, i.e., Bacillus velezensis, B. mojavensis, and B. methylotrophicus, were shown able to solubilize phosphate as previously demonstrated by Kalai-Grami et al. (2014). Furthermore, Pseudomonas spp., Serratia spp., Yokenella regensburgei, and Stenotrophomonas were capable to produce phosphatase (Ngamau et al. 2012; Ngoma et al. 2013).

\section{IAA production}

The 7 selected endophytic isolates were able to produce the IAA after $48 \mathrm{~h}$ of incubation (Table 2). The highest IAA production, of about $20.5-24.8 \mu \mathrm{g} /$ $\mathrm{ml}$, was recorded on S. maltophilia S23 and S. maltophilia S24 cultures, followed by $S$. marcescens 
Table 2 Antagonistic and plant growth-promoting (PGP) mechanisms of the seven selected endophytic bacterial isolates recovered from Solanum sodomaeum and Solanum bonariense

\begin{tabular}{|c|c|c|c|c|c|c|c|}
\hline \multirow{3}{*}{$\begin{array}{l}\text { Solanum } \\
\text { spp. }\end{array}$} & \multirow{3}{*}{$\begin{array}{l}\text { Bacterial } \\
\text { isolates }\end{array}$} & \multicolumn{4}{|c|}{ Antagonistic traits } & \multirow{2}{*}{\multicolumn{2}{|c|}{ PGP ability }} \\
\hline & & \multicolumn{3}{|c|}{ Hydrolytic enzymes } & \multirow{2}{*}{$\begin{array}{l}\text { Volatile antibiotic } \\
\mathrm{HCN}^{\text {d }}\end{array}$} & & \\
\hline & & Chitinase $^{\mathrm{a}}$ & Protease $^{b}$ & Pectinase $^{c}$ & & Phosphate solubilization $^{\mathrm{e}}$ & $I A A^{f}$ \\
\hline \multirow[t]{4}{*}{ S. sodomaeum } & S11 & + & ++ & + & + & - & + \\
\hline & S14 & + & + & + & - & + & ++ \\
\hline & S28 & + & + & + & + & ++ & ++ \\
\hline & S26 & - & + & + & - & - & ++ \\
\hline \multirow[t]{3}{*}{ S. bonariense } & S23 & + & ++ & + & - & - & +++ \\
\hline & S24 & + & ++ & + & - & - & +++ \\
\hline & SV81 & + & - & + & - & + & + \\
\hline
\end{tabular}

S11, Azotobacter chroococcum; S14, Serratia marcescens; S23, S24, S26, and S28, Stenotrophomonas maltophilia; SV81, Bacillus sp.

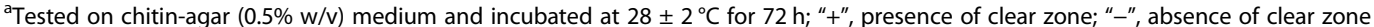

${ }^{\mathrm{b}}$ Tested on skim milk agar ( $\left.3 \% \mathrm{v} / \mathrm{v}\right)$ medium and incubated at $28 \pm 2{ }^{\circ} \mathrm{C}$ for $48 \mathrm{~h}$; " + " and "++", presence of clear zone (15.67 to 25 and 30 to $45.83 \mathrm{~mm}$ in diameter, respectively); "-", absence of clear zone

'Tested on pectin-agar $(0.5 \% \mathrm{w} / \mathrm{v})$ medium and incubated at $28 \pm 2{ }^{\circ} \mathrm{C}$ for $48 \mathrm{~h}$; " + ", presence of clear zone

${ }^{\mathrm{d}} \mathrm{HCN}$, hydrogen cyanide production on glycine-agar $(4.4 \mathrm{~g} / \mathrm{L} \mathrm{w} / \mathrm{v})$ medium and incubated at $25^{\circ} \mathrm{C}$ for 4 days; " + ", modification on the filter paper color (lightreddish color) compared to the control (yellow); "-", no modification on the filter paper color (yellow)

'Tested on Pikovskaya agar medium and incubated at $28 \pm 2{ }^{\circ} \mathrm{C}$ for 7 days; " + " and " ++ ", presence of clear zone (8.33-9.8 and $13.17 \mathrm{~mm}$ in diameter, respectively); "-", absence of clear zone

${ }^{\mathrm{f}} / A A$, indole-3-acetic acid production after $48 \mathrm{~h}$ of incubation at $28 \pm 2{ }^{\circ} \mathrm{C}$ in Luria-Broth medium; " + ", " ++ ", and "+++", production of IAA (5-9.4, $14.38-18.71$, and

$20.5-24.8 \mu \mathrm{g} / \mathrm{ml}$, respectively)

S14, S. maltophilia S28, S. maltophilia S26 (14.38$18.71 \mu \mathrm{g} / \mathrm{ml})$, and A. chroococcum S11 and Bacillus sp. SV81 $(5-9.4 \mu \mathrm{g} / \mathrm{ml})$. Many scientific reports have explained the ability of endophytic bacteria to stimulate the secretion of plant growth hormones and enhance their growth-promoting activity. In this study, remarkably efficient growth promotion was stimulated by the 7 selected bacterial isolates in tomato-free pathogen plants and those inoculated with FOL, which was due to their ability to produce IAA. Many previous studies reported the ability of endophytic bacteria to produce IAA such as $B$. thuringiensis, B. subtilis, Bacillus arbutinivorans, Bacillus fusiformis, Bacillus megaterium (Wang et al. 2013), S. maltophilia (Ngoma et al. 2013), S. marcescens (Selvakumar et al. 2008), and Serratia nematodiphila (Dastager et al. 2011).

\section{Conclusions}

The present study emphasized the importance of the wild solanaceous species, $S$. sodomaeum and $S$. bonariense, as potential sources for isolation of beneficial endophytic bacteria acting as plant growthpromoter and a biocontrol agent on both pathogenfree and FOL-inoculated tomato plants. Seven isolates were identified as the most effective bio-agent. Their plant growth-promoting abilities were confirmed via IAA production and phosphate solubilization activities. The 7 selected bacterial isolates displayed interesting enzymatic activity and 3 of them were shown able to produce $\mathrm{HCN}$. The diffusible and volatile metabolites produced by these isolates were effective against FOL mycelial growth. These isolates will be further tested for their potential to suppress Fusarium wilt and to promote growth and production of tomato grown under naturally infested and non-infested soils.

\section{Abbreviations \\ F. oxysporum: Fusarium oxysporum; F. verticillioides: Fusarium verticillioides; $R$. solani: Rhizoctonia solani; S. maltophilia: Stenotrophomonas maltophilia; A. chroococcum: Azotobacter chroococcum; S. marcescens: Serratia marcescens; A. faecalis: Alcaligenes faecalis; $P$. aeruginosa: Pseudomonas aeruginosa; $B$. thuringiensis: Bacillus thuringiensis; $B$. cereus: Bacillus cereus; $B$. \\ mojavensis: Bacillus mojavensis; $B$. tequilensis: Bacillus tequilensis; $B$. subtilis: Bacillus subtilis; $B$. arbutinivorans: Bacillus arbutinivorans; $B$. fusiformis: Bacillus fusiformis; B. megaterium: Bacillus megaterium; $B$. velezensis: Bacillus velezensis; S. sodomaeum: Solanum sodomaeum; $S$. bonariense: Solanum bonariense; W. somnifera: Withania somnifera; S. elaeagnifolium: Solanum elaeagnifolium; S. linnaeanum: Solanum linnaeanum; D. metel: Datura metel; N. glauca: Nicotiana glauca; PDA: Potato dextrose agar; NB: Nutrient broth; NA: Nutrient agar; SDW: Sterile distilled water; DPI: Days post-inoculation; FOL: Fusarium oxysporum f. sp. Iycopersici; IAA: Indole-3-acetic acid; HCN: Hydrogen cyanide}

\section{Acknowledgements}

Authors would like to thank Dr. Sonia Mokni-Tlili for assistance with molecular identification of bacterial isolates and all the staff of Research Centre and Water Technology of Borj Cedria, Tunisia, for providing necessary facilities.

\section{Authors' contributions}

The concept and design of the experiments were prepared by all authors. RAB conducted the experiments, analyzed the results, and wrote the manuscript. HJK coordinated the laboratory as well as in greenhouse works. MDR supervised the results analysis and corrected the manuscript draft. All authors have read and approved the manuscript.

\section{Funding}

This work was funded by the Ministry of Higher Education and Scientific Research of Tunisia through the funding allocated to the research unit 
UR13AGR09-Integrated Horticultural Production in the Tunisian Centre-East, Regional Research Centre on Horticulture and Organic Agriculture of ChottMariem, Tunisia.

\section{Availability of data and materials}

All data generated and/or analyzed during the present study are available in the manuscript, and the corresponding author has no objection to the availability of data and materials.

\section{Ethics approval and consent to participate}

The study was conducted on plant-pathogen fungus and beneficial entophytic bacteria that are abundant in the environment and do not require ethical approval.

\section{Consent for publication}

Not applicable.

\section{Competing interests}

All authors declare that they have no conflict of interest.

Received: 18 June 2020 Accepted: 31 August 2020

Published online: 11 September 2020

\section{References}

Achari GA, Ramesh R (2014) Diversity, biocontrol, and plant growth promoting abilities of xylem residing bacteria from Solanaceous crops. Inter J Microbiol 2014:1-14

Algam SA, Guan-lin X, Coosemans J (2005) Delivery methods for introducing endophytic Bacillus into tomato and their effect on growth promotion and suppression of tomato wilt. Plant Pathol J 4:69-74

Amini J (2009) Physiological race of Fusarium oxysporum f. sp. lycopersici in Kurdistan province of Iran and reaction of some tomato cultivars to race 1 of pathogen. Plant Pathol J 8:68-73

Aydi Ben Abdallah R, Jabnoun-Khiareddine H, Mokni-Tlili S, Nefzi A, MedimaghSaidana S, Daami-Remadi M (2015) Endophytic Bacillus spp. from wild Solanaceae and their antifungal potential against Fusarium oxysporum f. sp lycopersici elucidated using whole cells, filtrate cultures and organic extracts. J Plant Pathol Microbiol 6:324-331

Aydi Ben Abdallah R, Jabnoun-Khiareddine H, Nefzi A, Ayed F, Daami-Remadi M (2019) Field suppression of Fusarium wilt and microbial population shifts in tomato rhizosphere following soil treatment with two selected endophytic bacteria. Eur J Soil Sci 8:208-220

Aydi Ben Abdallah R, Jabnoun-Khiareddine H, Nefzi A, Mokni-Tlili S, DaamiRemadi M (2016b) Endophytic bacteria from Datura metel for plant growth promotion and bioprotection against Fusarium wilt in tomato. Biocontrol Sci Technol 26:1139-1165

Aydi Ben Abdallah R, Jabnoun-Khiareddine H, Nefzi A, Mokni-Tlili S, DaamiRemadi M (2016c) Endophytic bacteria from Datura stramonium for Fusarium wilt suppression and tomato growth promotion. J Microb Biochem Technol 8:30-41

Aydi Ben Abdallah R, Mejdoub-Trabelsi B, Nefzi A, Jabnoun-Khiareddine $\mathrm{H}_{\text {, }}$ Daami-Remadi M (2016e) Isolation of endophytic bacteria from Withania somnifera and assessment of their ability to suppress Fusarium wilt disease in tomato and to promote plant growth. J Plant Pathol Microbiol 7:352-362

Aydi Ben Abdallah R, Mokni-Tlili S, Nefzi A, Jabnoun-Khiareddine H, DaamiRemadi M (2016d) Biocontrol of Fusarium wilt and growth promotion of tomato plants using endophytic bacteria isolated from Nicotiana glauca organs. Biol Control 97:80-88

Aydi Ben Abdallah R, Nefzi A, Jabnoun-Khiareddine H, Mokni-Tlili S, DaamiRemadi M (2016a) Biocontrol of Fusarium wilt and growth promotion of tomato plants using endophytic bacteria isolated from Solanum elaeagnifolium stems. J Phytopathol 164:811-824

Aydi Ben Abdallah R, Stedel C, Garagounis C, Nefzi A, Jabnoun-Khiareddine H, Papadopoulou KK, Daami-Remadi M (2017) Involvement of lipopeptide antibiotics and chitinase genes and induction of host defense in suppression of Fusarium wilt by endophytic Bacillus spp. in tomato. Crop Prot 99:45-58

AydiBenAbdallah R, Jabnoun-Khiareddine H, Daami-Remadi M (2019) Exploring the beneficial endophytic microorganisms for plant growth promotion and crop protection : elucidation of some bioactive secondary metabolites involved in both effects. In: Singh HB, Keswani C, Reddy MS, Sansinenea E,
García-Estrada C (eds) Secondary metabolites of plant growth promoting rhizomicroorganisms. Springer Nature, Singapore

Bari MA, Slam WI, Khan AR, Mandal A (2010) Antibacterial and antifungal activity of Solanum torvum (Solanaceae). Inter J Agri Biol 12:386-390

Ben Slama H, Triki MA, Bouket AC, Ben Mefteh F, Alenezi FN, Luptakova L, CherifSilini H, Vallat A, Oszako T, Gharsallah N, Belbahri L (2019) Screening of the high-rhizosphere competent Limoniastrum monopetalum' culturable endophyte microbiota allows the recovery of multifaceted and versatile biocontrol agents. Microorganisms 7:249-277

Berg G, Krechel A, Ditz M, Sikora RA, Ulrich A, Hallmann J (2005) Endophytic and ectophytic potato-associated bacterial communities differ in structure and antagonistic function against plant pathogenic fungi. FEMS Microbiol Ecol 51:215-229

Bhuvaneswari S, Madhavan S, Panneerselvam A (2013) Enumeration of endophytic bacteria from Solanum trilobatum L. World J Pharm Res 3:22702279

Chaurasia B, Pandey A, Palnib LMS, Trivedi P, Kumar B, Colvin N (2005) Diffusible and volatile compounds produced by an antagonistic Bacillus subtilis strain cause structural deformations in pathogenic fungi in vitro. Microbiol Res 160: $75-81$

Chen C, Bauske EM, Musson G, Rodríguez-Kábana R, Kloepper JW (1995) Biological control of Fusarium wilt on cotton by use of endophytic bacteria. Biol Control 5:83-91

Constantin ME, de Lamo FJ, Vlieger BV, Rep M, Takken FLW (2019) Endophytemediated resistance in tomato to Fusarium oxysporum is independent of ET, JA, and SA. Front Plant Sci 10:979-992

Dastager SG, Deepa CK, Pandey A (2011) Potential plant growth-promoting activity of Serrratia nematodiphilia NII-0928 on black pepper (Piper nigrum L.). World J Microbiol Biotechnol 27:259-265

de Lamo FJ, Constantin ME, Fresno DH, Boeren S, Rep M, Takken FLW (2018) Xylem sap proteomics reveals distinct differences between $\mathrm{R}$ gene- and endophyte-mediated resistance against Fusarium wilt disease in tomato. Front Microbiol 9:2977-2989

Deketelaere S, Tyvaert L, França SC, Höfte M (2017) Desirable traits of a good biocontrol agent against Verticillium wilt. Front Microbiol 8:1186-1209

Doan HK, Maharaj NN, Kelly KN, Miyao EM, Davis RM, Leveau HJ (2020) Antimycotal activity of Collimonas isolates and synergy-based biological control of Fusarium wilt of tomato. Phytobiomes J 4:64-74

Egamberdieva D, Wirth SJ, Shurigin W, Hashem A, Abd Allah EF (2017) Endophytic bacteria improve plant growth, symbiotic performance of chickpea (Cicer arietinum L.) and induce suppression of root rot caused by Fusarium solani under salt stress. Front Microbiol 8:1887

Fatima S, Anjum T (2017) Identification of a potential ISR determinant from Pseudomonas aeruginosa PM12 against Fusarium wilt in tomato. Front Plant Sci 8:848-861

Gyaneshwar P, James EK, Mathan N, Reddy PM, Reinhold-Hurek B, Ladha JK (2001) Endophytic colonization of rice by a diazotrophic strain of Serratia marcescens. J Bacteriol 183:2634-2645

Hussain I, Alam SS, Khan I, Shah B, Naeem A, Khan N, Shah SRA (2016) Study on the biological control of Fusarium wilt of tomato. J Entomol Zool Stud 4:525-528

Kalai-Grami L, Saidi S, Bachkouel S, Ben Slimene I, Mnari-Hattab M, Hajlaoui MR, Limam F (2014) Isolation and characterization of putative endophytic bacteria antagonistic to Phoma tracheiphila and Verticillium albo-atrum. Appl Bioch Biotechnol 174:365-375

Kha N, Martínez-Hidalgo P, Ice TA, Maymon M, Humm EA, Nejat N, Sanders ER, Kaplan D, Hirsch AM (2018) Antifungal activity of Bacillus species against Fusarium and analysis of the potential mechanisms used in biocontrol. Front Microbiol 9:2363

Koohakan P, Prasom P, Sikhao P (2020) Application of seed coating with endophytic bacteria for Fusarium wilt disease reduction and growth promotion in tomato. Int J Agr Technol 16:55-62

Lasudee K, Tokuyama S, Lumyong S, Pathom-aree W (2018) Actinobacteria associated with arbuscular mycorrhizal Funneliformis mosseae spores, taxonomic characterization and their beneficial traits to plants: evidence obtained from mung bean (Vigna radiata) and thai jasmine rice (Oryza sativa). Front Microbiol 9:1247

Lugtenberg B, Malfanova N, Kamilova F, Berg G (2013) Microbial control of plant diseases. In: de Bruijn FJ (ed) Molecular microbial ecology of the rhizosphere. Wiley-Blackwell, New York

Mrkova-ki N, Kova-ev L, Øv N, Mezei S (2001) Application of microbiological preparation in sugar beet production. A Period Sci Res Field Veget Crops 35: $67-73$ 
Murray PR, Baron EJ, Jorgensen JJ, Pfaller MA, Yolken RH (2003) Manual of clinical microbiology. ASM Press, Washington, p 2310

Nagarajkumar M, Bhaskaran R, Velazhahan R (2004) Involvement of secondary metabolites and extracellular lytic enzymes produced by Pseudomonas fluorescens in inhibition of Rhizoctonia solani, the rice sheath blight pathogen. Microbiol Res 159:73-81

Nawangsih AA, Damayanti I, Wiyono S, Kartika JG (2011) Selection and characterization of endophytic bacteria as biocontrol agents of tomato bacterial wilt disease. J Biosci 18:66-70

Nefzi A, Aydi Ben Abdallah R, Jabnoun-Khiareddine H, Ammar N, MedimaghSaïdana S, Daami-Remadi M (2018a) Management of Fusarium crown and root rot of tomato by Solanum linnaeanum L. extract. Sci Horti 238:204-214

Nefzi A, Aydi Ben Abdallah R, Jabnoun-Khiareddine H, Ammar N, Somai L, DaamiRemadi M (2018b) Investigation on biosuppression of Fusarium crwon and root rot of tomato (Solanum lycopersicum L.) and growth promotion using fungi naturally associated to Solaum linnaeanum L. Afr J Microbiol Res 12: 152-170

Ngamau CN, Matiru VN, Tani A, Muthuri CW (2012) Isolation and identification of endophytic bacteria of bananas (Musa spp.) in Kenya and their potential as biofertilizers for sustainable banana production. Afr J Microbiol Res 6:6414-6422

Ngoma L, Esau B, Babalola OO (2013) Isolation and characterization of beneficial indigenous endophytic bacteria for plant growth promoting activity in Molelwane Farm, Mafikeng, South Africa. Afr J Biotechnol 12:4105-4114

Passari AK, Upadhyaya K, Singh G, Abdel Azeem AM, Thankappan S, Uthandi S, Hashem A, Abd Allah EF, Malik JA, Alqarawi AS, Gupta VK, Ranjan S, Singh BP (2019) Enhancement of disease resistance, growth potential, and photosynthesis in tomato (Solanum lycopersicum) by inoculation with an endophytic actinobacterium, Streptomycesthermocarboxydus strain BPSAC147. PLoS One 14:1-20

Patel HA, Patel RK, Khristi SK, Parikh K, Rajendran G (2012) Isolation and characterization of bacterial endophytes from Lycopersicon esculentum plant and their plant growth promoting characteristics. Nepal J Biotechnol 2:37-52

Ramyabharathi SA, Raguchander T (2014) Efficacy of secondary metabolites produced by Bacillus subtilis EPCO16 against tomato wilt pathogen Fusariumoxysporum f. sp. Iycopersici. J Mycol Plant Pathol 44:148-153

Rosenblueth M, Martínez-Romero E (2006) Bacterial endophytes and their interactions with hosts. Mol Plant-Microbe Interact 19:827-837

Schaad NW, Jones JB, Chun W (2001) Laboratory guide for identification of plant pathogenic bacteria. American Phytopathological Society, St Paul, 373.

Selvakumar G, Mohan M, Kundu S, Gupta AD, Joshi P, Nazim S, Gupta HS (2008) Cold tolerance and plant growth promotion potential of Serratiamarcescens strain SRM (MTCC 8708) isolated from flowers of summer squash (Cucurbita pepo). Lett Appl Microbiol 46:171-175

Sgroy V, Cassán F, Masciarelli O, Del Papa MF, Lagares A, Luna V (2009) Isolation and characterization of endophytic plant growth-promoting (PGPB) or stress homeostasis-regulating (PSHB) bacteria associated to the halophyte Prosopisstrombulifera. Appl Microbiol Biotechnol 85:371-381

Shahzad R, Khan AL, Bilal S, Asaf S, Lee IJ (2017) Plant growth-promoting endophytic bacteria versus pathogenic infections: an example of Bacillus amyloliquefaciens RWL-1 and Fusarium oxysporum f. sp. lycopersici in tomato. PeerJ 5:1-21

Someya N, Kataoka N, Komagata T, Hirayae K, Hibi T, Akutsu K (2000) Biological control of cyclamen soilborne diseases by Serratia marcescens strain B2. Plant Dis $84: 334-340$

Timmusk S, Behers L, Muthoni J, Muraya A, Aronsson AC (2017) Perspectives and challenges of microbial application for crop improvement. Front Plant Sci 8:49

Tiru M, Muleta D, Bercha G, Adugna G (2013) Antagonistic effect of rhizobacteria against coffee wilt disease caused by Gibberella xylarioides. Asian J Pathol 7: 109-122

Tuba M, Abidi M, Shaukat SS, Shaik A (2016) Antifungal activity of methanolic extracts of some indigenous plants against common soil borne fungi. Pak J Bot 48:749-752

Vurukonda SSKP, Giovanardi D, Stefani E (2018) Plant growth promoting and biocontrol activity of Streptomyces spp. as endophytes. Int J Mol Sci 19:952-977

Wang S, Wang W, Jin Z, Du B, Ding Y, Ni T, Jiao F (2013) Screening and diversity of plant growth promoting endophytic bacteria from peanut. Afr J Microbiol Res 7:875-884

Waqas M, Khan AL, Hamayun M, Shahzad R, Kim Y-H, Choi KS, Lee IJ (2015) Endophytic infection alleviates biotic stress in sunflower through regulation of defence hormones, antioxidants and functional amino acids. Eur J Plant Pathol 141:803-8240
Zhu B, Liu H, Tian WX, Fan XY, Li B, Zhou XP, Jin GL, Xiea GL (2012) Genome sequence of Stenotrophomonas maltophilia RR-10, isolated as an endophyte from rice root. J Bacteriol 194:1280-1281

\section{Publisher's Note}

Springer Nature remains neutral with regard to jurisdictional claims in published maps and institutional affiliations.

\section{Submit your manuscript to a SpringerOpen ${ }^{\circ}$ journal and benefit from:}

- Convenient online submission

- Rigorous peer review

- Open access: articles freely available online

- High visibility within the field

- Retaining the copyright to your article

Submit your next manuscript at $\boldsymbol{\nabla}$ springeropen.com 